\title{
Growth Suppression of Cancer Spheroids With Mutated KRAS by Low-toxicity Compounds from Natural Products
}

\author{
SAYURI HASHIMOTO ${ }^{1}$, MASAYOSHI NAGAI ${ }^{1}$, KENSUKE NISHI $^{1,2}$, SHUHEI ISHIKURA ${ }^{1,3}$, \\ KAZUHIKO NAKABAYASHI ${ }^{4}$, RYO YAZAKI ${ }^{5}$, TAKASHI OHSHIMA ${ }^{5}$, \\ MASAHIKO SUENAGA ${ }^{6}$, SENJI SHIRASAWA ${ }^{1,3}$ and TOSHIYUKI TSUNODA ${ }^{1,3}$ \\ ${ }^{1}$ Department of Cell Biology, Faculty of Medicine, and \\ ${ }^{3}$ Central Research Institute for Advanced Molecular Medicine, Fukuoka University, Fukuoka, Japan; \\ ${ }^{2}$ Section of Otolaryngology, Department of Medicine, Fukuoka Dental College, Fukuoka, Japan; \\ ${ }^{4}$ Department of Maternal-Fetal Biology, National Center for Child Health and Development, Tokyo, Japan; \\ ${ }^{5}$ Graduate School of Pharmaceutical Sciences, and \\ ${ }^{6}$ Department of Chemistry, Graduate School of Science, Kyushu University, Fukuoka, Japan
}

\begin{abstract}
Background/Aim: Among compounds from natural products selectively suppressing the growth of cancer spheroids, which have mutant (mt) KRAS, NP910 was selected and its derivatives explored. Materials and Methods: The area of HKe3 spheroids expressing wild type (wt) KRAS (HKe3wtKRAS) and mtKRAS (HKe3-mtKRAS) were measured in three-dimensional floating $(3 D F)$ cultures treated with 18 NP910 derivatives. The $50 \%$ cell growth inhibition (GI50) was determined by long-term $3 D F(L T 3 D F)$ culture and nude mice assay. Results: We selected NP882 (named STAR3) as the most effective inhibitor of growth of HKe3-mtKRAS spheroids with the least toxicity among NP910 derivatives. GI50s of STAR3 in LT3DF and nude mice assay were $6 \mu M$ and $30.75 \mathrm{mg} / \mathrm{kg}$, respectively. However, growth suppression by STAR3 was observed in 50\% of cell lines independent of KRAS mutation, suggesting that the target of STAR3 was not directly associated with KRAS mutation and KRAS-related signals. Conclusion: STAR3 is a low-toxicity compound that inhibits growth of certain tumour cells.
\end{abstract}

KRAS is the most frequently mutated oncogene among human cancers (1), with high rates of activating missense

This article is freely accessible online.

Correspondence to: Toshiyuki Tsunoda, MD, Ph.D., Department of Cell Biology, Faculty of Medicine Fukuoka University, 7-45-1 Nanakuma, Jonan-ku, Fukuoka 814-0180, Japan. Tel: +81 928011011, Fax: +81 928643865, e-mail: tsunoda@fukuoka-u.ac.jp

Key Words: Colorectal cancer, KRAS, 3D floating culture, natural products. mutations in pancreatic cancers (86 to $96 \%$ ) (2), in colorectal cancers (CRC) (40 to 54\%), and in non-small cell lung cancer (NSCLC) (15 to 20\%) $(3,4)$. Once activated, mutated RAS remains "on" persistently, thereby enhancing downstream signalling and leading tumourigenesis. Recently, AMG510, which targets specifically KRAS G12C mutant, was developed and was found to be effective in clinical trials in some patients with NSCLC (5). However, the KRAS G12C mutation occur in about $13 \%$ of NSCLCs $(6,7)$, in 3 to $5 \%$ of CRCs, and in 1 to $2 \%$ of various other solid cancers $(3,5$, 8-10). Therefore, the range of use of AMG510 is limited, and the KRAS mutation is still an "undruggable" target.

Canonical anticancer agents, including alkylating drugs, platinum compounds, antimetabolites, topoisomerase inhibitors, and microtubule inhibitors, are highly toxic and cause serious side effects such as myelosuppression $(11,12)$. Recently, molecularly targeted drugs are expected to be the new drugs with low toxicity (13); however, drug resistance is unavoidable (14). Therefore, new types of compounds are indispensable for cancer treatment.

Recently, we screened genes that were up-regulated by mtKRAS in a three-dimensional (3D) matrigel culture and found that the phosphodiesterase 4B (PDE4B) levels were higher in clinical tumour samples from CRC patients in comparison to those from healthy control (15). We examined several PDE4 inhibitors, such as pan PDE4 inhibitor, resveratrol, and PDE4 selective inhibitor, apremilast $(16,17)$, revealing that these compounds are selective for cancer spheroids with mtKRAS, and exhibit high efficacy and low toxicity. Notably, resveratrol, which has similar PDE4inhibitory activity to that of rolipram (16), is present in various natural products, suggesting that some compounds from natural products will become low-toxicity anticancer agents. 
To screen compounds from natural products, we established 3D floating (3DF) culture using HKe3-wtKRAS (normal model) and HKe3-mtKRAS (cancer model) spheroids. Using this system as pilot screening, we identified a 5-bromouridine (BrUrd) (18); uridine derivatives may be able to target HKe3-mtKRAS spheroids selectively and may exhibit low-level toxicity to wtKRAS.

This study, utilized natural product libraries from RIKEN Natural Products Depository (NPDepo) and found several core compounds, including NP910 (19) and explored the efficacy of NP910 derivatives using 3DF culture. We selected NP882 (19) as lead compound and further examined its properties.

\section{Materials and Methods}

Compounds. Compounds library from natural products were kindly provided by RIKEN NPDepo (Saitama, Japan). Chemical distances were determined by the Jaccard similarity index (20).

Cell culture. HKe3, HKe3-wtKRAS, and HKe3-mtKRAS cultures were established and maintained as described previously $(21,22)$. DLD-1, SW620, SW837, A549, MIA PaCa2, Hs766T, HepG2, HEC1-B, CCK-81, Hs700T, SK-M EL-28, A498, DU145, MCF-7, $\mathrm{HeLa}, \mathrm{Caov}-3$ cells were purchased from the American Type Culture Collection (ATCC, Manassas, VA, USA) and maintained at $37^{\circ} \mathrm{C}$ in $5 \% \mathrm{CO}_{2}$ atmosphere in Dulbecco's modified Eagle's medium supplemented with $10 \%$ fetal bovine serum and $1 \%$ penicillin/streptomycin as described previously $(21,22)$.

Short-term 3D floating cell culture. Cells were seeded in 96-well plates with round-bottom and ultralow attachment surfaces (product number 7007; Corning Inc., Corning, NY, USA) and treated with a drug at day 0 . Cells were maintained at $37^{\circ} \mathrm{C}$ in $5 \% \mathrm{CO}_{2}$ atmosphere as described previously $(18,22,23)$.

Long-term 3D floating cell culture. Cells were seeded in 96-well plates and treated with a drug at day 0 . The drug added every three days and the area of spheroids was measured every three to four days until day 27 as previously described (18).

Measurement of area of spheroids. Photomicrographs of cells were taken and analyzed using an IN Cell Analyzer 1000 (GE Healthcare, Little Chalfont, UK) and IN Cell Developer Toolbox (GE Healthcare). The relative growth rate was calculated from a comparison of the area of control spheroids at day three.

Assay for tumourigenicity. Four-week-old female SHO mice (Crlj:SHO-Prkdc ${ }^{\text {scid } H} r^{h r}$ ) were purchased from Charles River Laboratories (Yokohama, Japan). Cells for implantation were trypsinized and re-suspended in a 1:1 mixture of phosphate-buffered saline and Matrigel (BD Bioscience, Bedford, MA, USA). A $100 \mu \mathrm{l}$ volume containing $1.5 \times 10^{6}$ HCT116 cells was subcutaneously injected into the flank of mice as described previously (17).

Statistical analyses. All experiments were performed in triplicate. Data are presented as means \pm standard deviations. Statistical analyses were performed using unpaired two-tailed Student's $t$-test in Microsoft Excel. $p$-Values of less than 0.05 were considered statistically significant.

\section{Results}

NP910 derivatives inhibit the growth of HKe3-mtKRAS cells grown in $3 D F$ cultures. During the first screening of compounds from natural products, NP910 was identified as a candidate drug that inhibits the growth of HKe3-mtKRAS spheroids but not HKe3-wtKRAS spheroids (data not shown). Eighteen NP910 derivatives were selected from RIKEN libraries of natural products using chemical distance (11) (Table I). Cells were treated with $16.6 \mu \mathrm{M}$ and $50.0 \mu \mathrm{M}$ of 18 NP910 derivatives in 3DF culture to examine the effects of NP910 derivatives on cell proliferation. The area of HKe3mtKRAS spheroids treated with $16.6 \mu \mathrm{M}$ of NP882 at day 6 was 1.27-fold larger in comparison to that of HKe3-wtKRAS spheroids treated with DMSO at day 6 (Figure 1A), suggesting that NP882 displays the highest efficacy for suppressing the growth of cancer cells. The area of HKe3-mtKRAS spheroids treated with $50.0 \mu \mathrm{M}$ of NP910, NP770, NP917, and NP882 at day 6, was 1.19-, 0.11-, 0.16-, and 0.86-fold smaller in comparison to that of HKe3-wtKRAS spheroids treated with DMSO at day 6, respectively (Figure 1B). The area of HKe3wtKRAS spheroids treated with $16.6 \mu \mathrm{M}$ of NP910, NP770, NP917, and NP882 at day 6 were 1.53-, 1.68-, 1.99-, and 2.01-fold larger in comparison to that of HKe3-wtKRAS spheroids treated with DMSO at day 6, respectively (Figure 1A), suggesting that NP917 and NP882 will show the lowest toxicity for normal cells. To select the best compounds from these derivatives, we scored the toxicity in the normal model (Hke3-wtKRAS) and the efficacy of growth suppression in the cancer model at a low or high dose. Furthermore, we used the growth rate from day 3 to day 6 in the cancer model for scoring (Table II). These results together suggest that NP882 (named STAR3) is a good candidate for further analyses.

The long-term effects of STAR3 for HKe3- wtKRAS and $m t K R A S$ spheroids. A long-term 3DF culture was established to determine the cytotoxicity of STAR3 during long-term exposure. The area of HKe3-wtKRAS spheroids treated with STAR3 at day 27 was similar to DMSO control (Figure 2A), suggesting that none of the drugs is cytotoxic to cells with wtKRAS. Treatment of HKe3-mtKRAS spheroids by serially-diluted STAR3 showed that the concentration required to achieve a $50 \%$ maximal inhibition in cell proliferation is approximately $6 \mu \mathrm{M}$ (Figure $2 \mathrm{~B}$ ).

Effect of STAR3 on in vivo tumourigenicity of human colorectal cancer HCT116 cells. HCT116 cells were injected subcutaneously into the nude mice to address the effects of STAR3 on tumourigenicity of HCT116 cells, STAR3 was administered on day 0. In control mice, tumour 
Table I. List of NP910 derivatives.

No.

\#75

NP910

Name

\#76

\#77

NP770

NP674

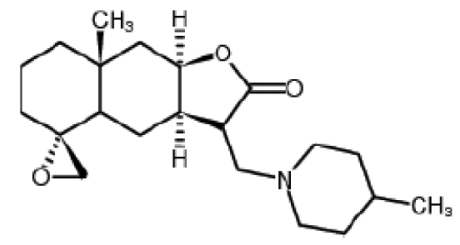

$\mathrm{C}_{21} \mathrm{H}_{33} \mathrm{NO}_{3} \quad 347.5 \quad 0.037$<smiles>CC1CCCCN1CC1C(=O)O[C@H]2C[C@@]3(C)CCC[C@]4(CO4)C3C[C@H]12</smiles>

$\mathrm{C}_{21} \mathrm{H}_{33} \mathrm{NO}_{3} \quad 347.5 \quad 0.059$

\#78

NP677

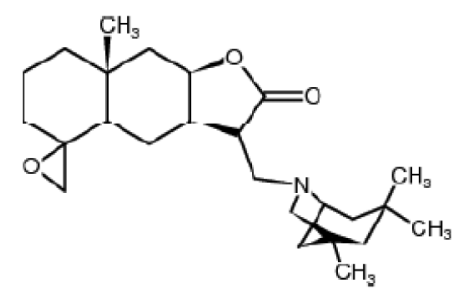

$\mathrm{C}_{25} \mathrm{H}_{39} \mathrm{NO}_{3}$

401.59

0.072

$\# 80$

NP716

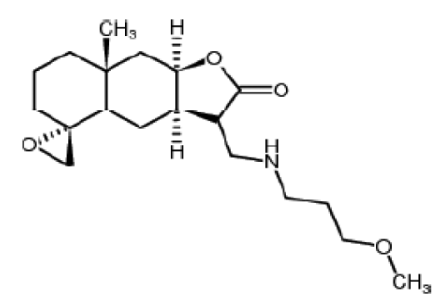

$\mathrm{C}_{19} \mathrm{H}_{31} \mathrm{NO}_{4}$

337.46

0.135<smiles></smiles>

\#81

NP917<smiles>CCOC(=O)C1CCN(C)CC1</smiles> 
Table I. Continued

No.

Name

Structure

Formula

M.W. Distance

\#82

NP862<smiles>CC12CCCC3(CO3)C1C[C@]1(C)C(CN3CCC(N4CCCCC4)CC3)C(=O)O[C@H]1C2</smiles>

$\mathrm{C}_{25} \mathrm{H}_{40} \mathrm{~N}_{2} \mathrm{O}_{3} \quad 416.6$

0.186

\#83

NP676<smiles>CC1CN(CC2C(=O)OC3C[C@@]4(C)CCCC5(CO5)C4CC32)CC(C)O1</smiles>

$\mathrm{C}_{21} \mathrm{H}_{33} \mathrm{NO}_{4} \quad 363.5 \quad 0.223$

\#84

NP678<smiles>C[C@H](CN(C)CC1C(=O)OC2CC3(C)CCCC4(CO4)C3CC21)[C@@H](O)c1ccccc1</smiles>

$\mathrm{C}_{26} \mathrm{H}_{37} \mathrm{NO}_{4} \quad 427.58 \quad 0.236$

\#85

NP882<smiles>CC12CCCC3(CO3)C1C[C@H]1C(CN3CCC(O)(Cc4ccccc4)CC3)C(=O)O[C@H]12</smiles>

$\mathrm{C}_{27} \mathrm{H}_{37} \mathrm{NO}_{4} \quad 427.58 \quad 0.24$

\#86

NP813

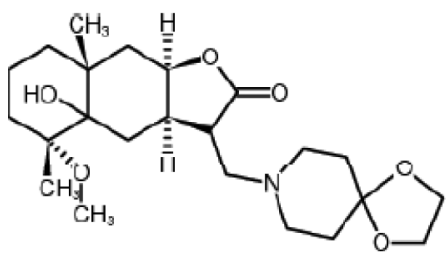

$\mathrm{C}_{23} \mathrm{H}_{37} \mathrm{NO}_{6} \quad 423.55 \quad 0.241$

\#87

NP842

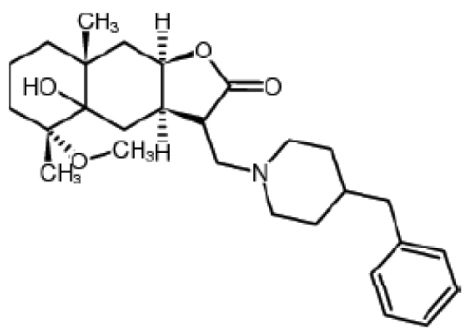

$\mathrm{C}_{28} \mathrm{H}_{41} \mathrm{NO}_{4} \quad 455.64 \quad 0.265$

\#88

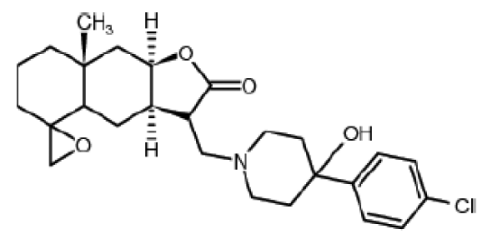

$\mathrm{C}_{28} \mathrm{H}_{34} \mathrm{CINO}_{4} \quad 460.01 \quad 0.288$ 
Table I. Continued

No.

\#89

NP713

\#90

NP1056

\#91

\#92

NP715

NP918<smiles>C[C@]12CCC[C@@]3(CO3)C1C[C@H]1C(CN3CCSCC3)C(=O)O[C@H]1C2</smiles>

$\mathrm{C}_{19} \mathrm{H}_{29} \mathrm{NO}_{3} \mathrm{~S} \quad 351.51 \quad 0.294$

$\mathrm{C}_{23} \mathrm{H}_{30} \mathrm{FNO}_{3} \quad 387.49 \quad 0.295$<smiles></smiles>

$\mathrm{C}_{24} \mathrm{H}_{35} \mathrm{NO}_{4} \quad 401.55 \quad 0.315$<smiles>CC(CCc1ccco1)N(C)CC1C(=O)O[C@H]2C[C@@]3(C)CCCC4(CO4)C3C[C@H]12</smiles>

$\mathrm{C}_{21} \mathrm{H}_{34} \mathrm{~N}_{2} \mathrm{O}_{4} \quad 378.51 \quad 0.353$

\#93

NP909

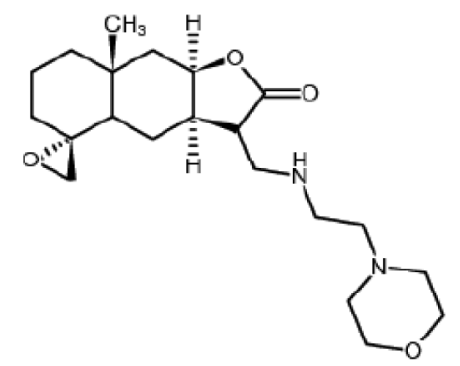

$\mathrm{C}_{22} \mathrm{H}_{28} \mathrm{FNO}_{3} \quad 373.47 \quad 0.375$<smiles>C[C@]12CCCC3(CO3)C1C[C@H]1C(CNCc3ccc(F)cc3)C(=O)O[C@H]12</smiles>

$\mathrm{C}_{24} \mathrm{H}_{33} \mathrm{NO}_{4}$ 399.53

0.388 

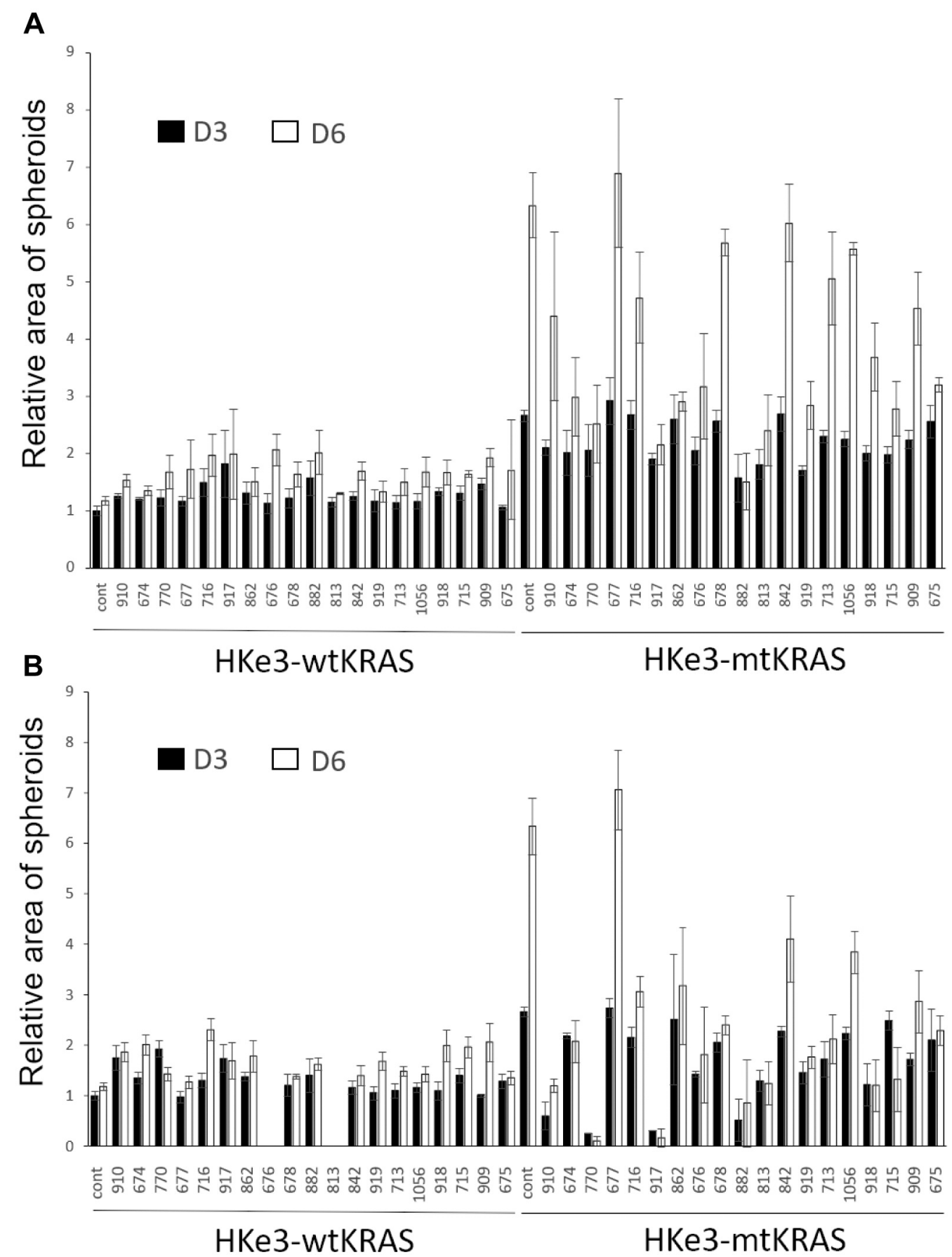

Figure 1. NP910 derivatives inhibit the growth of HKe3-mutant (mt) KRAS spheroids. The relative area of spheroids of HKe3-wild type (wt) KRAS and HKe3-mtKRAS treated with NP910 derivatives at day three and day six compared to that of HKe3-wtKRAS treated with dimethyl sulfoxide (DMSO, control) at day 3. The concentration of NP910 derivatives was $16.6 \mu M(A)$ or $50 \mu M(B)$.

volume was $2362 \mathrm{~mm}^{3}$ on day 7 . In contrast, in mice treated with $10 \mathrm{mg} / \mathrm{kg}, 40 \mathrm{mg} / \mathrm{kg}$ and $50 \mathrm{mg} / \mathrm{kg}$ STAR3 tumour volume was $1985 \mathrm{~mm}^{3}, 750 \mathrm{~mm}^{3}$, and $514 \mathrm{~mm}^{3}$, at day 7 , respectively (Figure 3). GI50 was $30.75 \mathrm{mg} / \mathrm{kg}$.
HCT116 cell tumour volume was dramatically reduced in in mice treated with STAR3 compared to those administered DMSO, suggesting that STAR3 inhibits tumour growth in vivo. 
Table II. Scoring method.

\begin{tabular}{|c|c|c|c|c|c|c|c|c|}
\hline $\begin{array}{l}\text { Chemical } \\
\text { name or } \\
\text { NPD No. }\end{array}$ & M.W. & $\begin{array}{c}\text { A } \\
\text { The area of HKe3- } \\
\text { mtKRAS spheroids } \\
\text { with } 16.6 \mu \mathrm{M} \\
\text { drugs at day } 6 \\
\text { is } 0 \sim 2 \text {-fold } \\
\text { increased (2p) } \\
\text { or 2 4-fold } \\
\text { increased (1p) } \\
\text { over 4-fold } \\
\text { increased (0p) } \\
\text { compared to that } \\
\text { of HKe3-wtKRAS } \\
\text { spheroids } \\
\text { with DMSO } \\
\text { control at day3. }\end{array}$ & $\begin{array}{c}\text { The area of HKe3- } \\
\text { mtKRAS spheroids } \\
\text { with } 50.0 \mu \mathrm{M} \\
\text { drugs at day } 6 \\
\text { is } 0 \sim 2 \text {-fold } \\
\text { increased (2p) } \\
\text { or 2 4-fold } \\
\text { increased. (1p) } \\
\text { over 4-fold } \\
\text { increased (0p) } \\
\text { compared to that } \\
\text { of HKe3-wtKRAS } \\
\text { spheroids } \\
\text { with DMSO } \\
\text { control at day3. }\end{array}$ & $\begin{array}{l}\text { The increased } \\
\text { ratio of } \\
\text { HKe3-mtKRAS } \\
\text { with } 16.6 \mu \mathrm{M} \\
\text { drugs from } \\
\text { day3 to day6. } \\
>1.5 \text { fold } \\
\text { increase: } 0 \mathrm{p}, \\
1.1 \sim 1.5 \text { fold } \\
\text { increase: } 1 \mathrm{p}, \\
0 \sim 1.1 \text { fold } \\
\text { increase: } 2 \mathrm{p}\end{array}$ & $\begin{array}{l}\text { The increased } \\
\text { ratio of } \\
\text { HKe3-mtKRAS } \\
\text { with } 50.0 \mu \mathrm{M} \\
\text { drugs from } \\
\text { day3 to day6. } \\
>1.5 \text { fold } \\
\text { increase: } 0 \mathrm{p}, \\
1.1 \sim 1.5 \text { fold } \\
\text { increase: } 1 \mathrm{p}, \\
0 \sim 1.1 \text { fold } \\
\text { increase: } 2 \mathrm{p}\end{array}$ & $\begin{array}{l}\text { The increased } \\
\text { ratio of } \\
\text { HKe3-wtKRAS } \\
\text { with } 16.6 \mu \mathrm{M} \\
\text { drugs from } \\
\text { day3 to day } 6 . \\
>1.5 \text { fold } \\
\text { increase: } 2 \mathrm{p}, \\
1.1 \sim 1.5 \text { fold } \\
\text { increase: } 1 \mathrm{p}, \\
0 \sim 1.1 \text { fold } \\
\text { increase: } 0 \mathrm{p}\end{array}$ & $\begin{array}{l}\text { The increased } \\
\text { ratio of } \\
\text { HKe3-wtKRAS } \\
\text { with } 50.0 \mu \mathrm{M} \\
\text { drugs from } \\
\text { day3 to day6. } \\
>1.5 \text { fold } \\
\text { increase: } 2 \mathrm{p}, \\
1.1 \sim 1.5 \text { fold } \\
\text { increase: } 1 \mathrm{p}, \\
0 \sim 1.1 \text { fold } \\
\text { increase: } 0 \mathrm{p}\end{array}$ & $\begin{array}{c}\mathrm{G}=\mathrm{A}+\mathrm{B}+\mathrm{C}+ \\
\mathrm{D}+\mathrm{E}+\mathrm{F} \\
\text { Total: } 12 \mathrm{p}\end{array}$ \\
\hline NP910 & 319,44 & 0 & 2 & 0 & 0 & 1 & 0 & 3 \\
\hline NP674 & 347,5 & 1 & 1 & 1 & 2 & 1 & 1 & 7 \\
\hline NP770 & 347,5 & 1 & 2 & 1 & 2 & 1 & 0 & 7 \\
\hline NP677 & 401,59 & 0 & 0 & 0 & 0 & 1 & 1 & 2 \\
\hline NP716 & 337,46 & 0 & 1 & 1 & 1 & 1 & 2 & 6 \\
\hline NP917 & 405,53 & 1 & 2 & 1 & 2 & 0 & 0 & 6 \\
\hline NP862 & 416,6 & 1 & 1 & 1 & 1 & 1 & 1 & 6 \\
\hline NP676 & 363,5 & 1 & 2 & 0 & 1 & 2 & 2 & 8 \\
\hline NP678 & 427,58 & 0 & 1 & 0 & 1 & 1 & 1 & 4 \\
\hline NP882 & 439,6 & 2 & 2 & 2 & 0 & 1 & 1 & 8 \\
\hline NP813 & 423,55 & 1 & 2 & 1 & 1 & 1 & 2 & 8 \\
\hline NP842 & 455,64 & 0 & 0 & 0 & 0 & 1 & 1 & 2 \\
\hline NP919 & 460,01 & 1 & 2 & 0 & 1 & 1 & 1 & 6 \\
\hline NP713 & 351,51 & 0 & 1 & 0 & 0 & 1 & 1 & 3 \\
\hline NP1056 & 387,49 & 0 & 1 & 0 & 0 & 1 & 1 & 3 \\
\hline NP918 & 401,55 & 1 & 2 & 0 & 2 & 1 & 1 & 7 \\
\hline NP715 & 378,51 & 1 & 2 & 1 & 2 & 1 & 1 & 8 \\
\hline NP909 & 373,47 & 0 & 1 & 0 & 0 & 1 & 1 & 3 \\
\hline NP675 & 399,53 & 1 & 1 & 1 & 2 & 2 & 0 & 7 \\
\hline
\end{tabular}

A

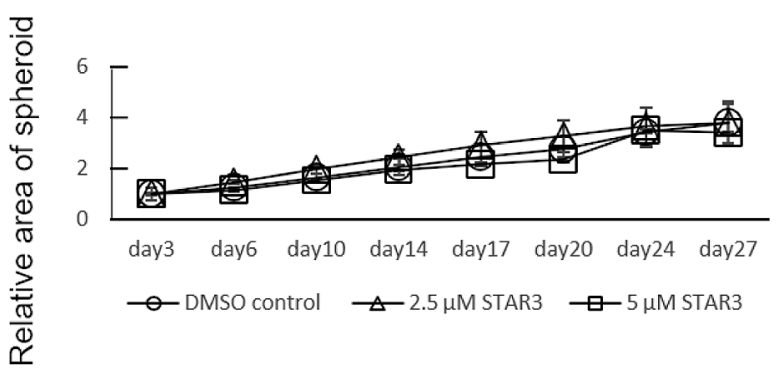

HKe3-wtKRAS
B

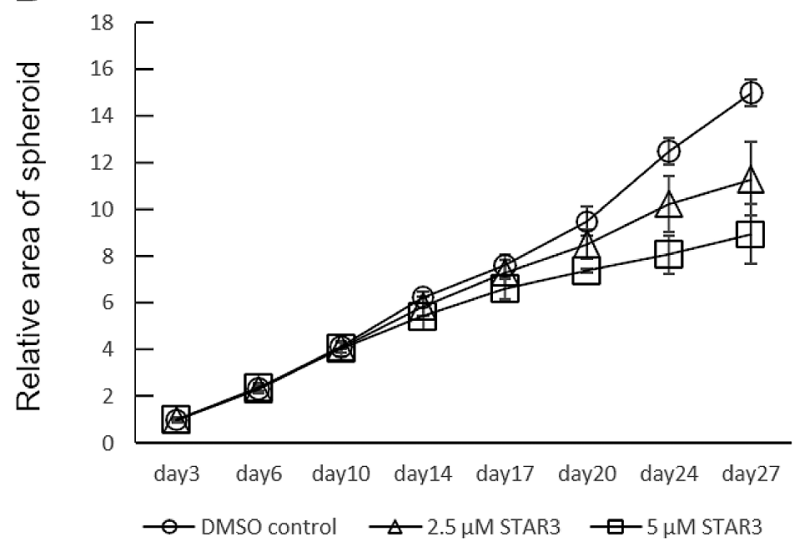

Figure 2. The long-term effect of STAR3 for HKe3-wild type (wt) KRAS and mutant (mt) KRAS spheroids A: Relative area of HKe3-wtKRAS spheroids treated with STAR3 from day 3 to day 27 compared to that for HKe3-wtKRAS treated with dimethyl sulfoxide (DMSO, control) at day 3. B: Relative area of HKe3-mtKRAS spheroids with STAR3 from day 3 to day 27 against HKe3-mtKRAS with dimethyl sulfoxide (DMSO) control at day 3. 


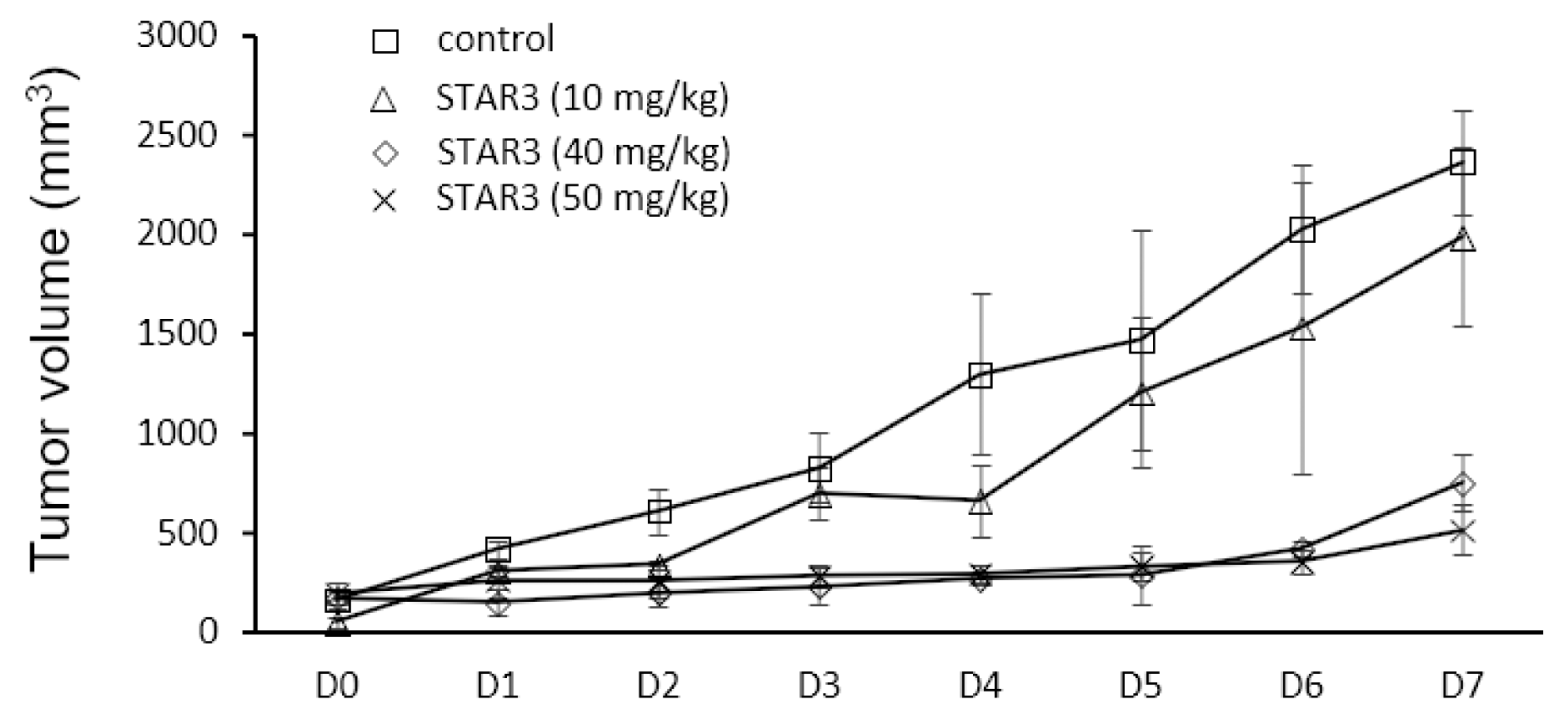

Figure 3. Effect of STAR3 on the in vivo tumourigenicity of human colorectal cancer HCT116 cells. HCT116 cells were injected subcutaneously into the flanks of nude mice. Relative tumour volumes are shown for mice treated with and without STAR3.

Table III. The effect of STAR3 in several cell lines with or without KRAS mutation.

\begin{tabular}{|c|c|c|c|c|}
\hline Tissue & Cell line & Type of $R A S$ mutation & Other sequence variations (ExSPASy) & The effect of STAR3 \\
\hline Colorectal & HCT 116 & KRAS (G13D) & $\begin{array}{c}\text { ACVR2A, BRCA2, CDKN2A, CTNNB, } \\
\text { EP300, PIK3CA, TGFBR2 }\end{array}$ & Positive \\
\hline Colorectal & HKe3-mtKRAS & KRAS (G13D) & $\begin{array}{c}\text { ACVR2A, BRCA2, CDKN2A, CTNNB, } \\
\text { EP300, PIK3CA, TGFBR2 }\end{array}$ & Positive \\
\hline Colorectal & DLD-1 & KRAS (G13D) & $\begin{array}{l}\text { ACVR2A, APC, B2M, EP300, } \\
\text { PIK3CA, TGFBR2, TP53 }\end{array}$ & Negative \\
\hline Colorectal & SW 620 & KRAS (G12V) & APC, TP53 & Positive \\
\hline Colorectal & SW 837 & KRAS (G12C) & APC, FBXW7, TP53 & Negative \\
\hline Lung & A549 & KRAS (G12S) & STK11 & Negative \\
\hline Pancreas & MIA PaCa2 & KRAS (G12C) & CDKN2A, TP53 & Positive \\
\hline Pancreas & Hs 766T & KRAS (Q61H) & SMAD4 & Positive (high conc) \\
\hline Liver & Hep G2 & NRAS (Q61L) & TERT & Positive \\
\hline Endometrium & HEC-1-B & KRAS (G12D) & TP53 & Negative \\
\hline Colorectal & CCK-81 & WT & FBXW, PIK3CA, TP53 & Negative \\
\hline Pancreas (meta) & Hs 700T & WT & TP53 & Negative \\
\hline Melanoma & SK-MEL-28 & WT & BRAF, CDK4, EGFR, PTEN, TERT, TP53 & Positive \\
\hline Kidney & A-498 & WT & VHL & Positive \\
\hline Prostate & DU145 & WT & CDKN2A, RB, STK1, TP53 & Negative \\
\hline Breast & MCF-7 & WT & CDKN2A, PIK3CA & Negative \\
\hline Cervix & HeLa & WT & & Positive \\
\hline Ovarian & Caov-3 & WT & TP53 & Negative \\
\hline
\end{tabular}

Efficacy of STAR3 on several cell lines. To examine the efficacy of STAR3 against other cell lines, 3DFCs were performed using 2, 6, 18, 54, and 162 (high concentration) $\mu \mathrm{M}$ of STAR3 (Table III). The number of cell lines in which STAR3 suppressed cell growth was $9(50 \%)$. The number of mtKRAS cell lines whose growth was suppressed by
STAR3, was $6(60 \%)$. On the other hand, the number of wtKRAS cell lines whose growth was suppressed by STAR3 was $3(37.5 \%)$. However, One-tailed Fisher's exact test did not show any significant difference between mtKRAS and wtKRAS cell lines. These results suggest that the target of STAR3 is not closely associated with KRAS-related signals. 


\section{Discussion}

In this study, we identified STAR3 as a potent drug for cancer with mtKRAS. In long-term 3DFC, GI50 was $6 \mu \mathrm{M}$, and drug resistance was not observed. Furthermore, STAR3 showed low toxicity and suppressed the growth of mtKRAS CRC in vivo. However, STAR3 was not effective in all cancer cell lines with or without mtKRAS, suggesting that the direct target is not associated with KRAS-related driver genes. There is a possibility that STAR3 will act through KRAS-unrelated genes, which are specific for cell lines. Identification of targets of STAR3 is needed for determining biomarkers and further developing STAR3.

Recent studies have reported the certain natural compounds that are effective against the KRAS-linked upstream and down-stream signalling pathways that are directly or indirectly linked with cell proliferation, division, and apoptosis $(24,25)$. We are now developing another compound (named STAR2) that shows low toxicity, and is effective against all mtKRAS cells.

\section{Conflicts of Interest}

The Authors declare no competing interests in relation to this study.

\section{Authors' Contributions}

S.H., M.N., K.N. and T.T. performed experiments, analysed the data, and wrote a manuscript draft. S.I., K.N., R.Y., and M.S participated in the study design, data collection, and analysis. T.O. and S.S. conceived the idea and designed the study, interpreted the data, provided important intellectual content, and obtained the final approval of the submitted manuscript.

\section{Acknowledgements}

The Authors would like to thank Yuriko Isoyama and Yumiko Hirose for their technical assistance. This work was supported by Grant-in-Aid for Scientific Research (C) (KAKENHI, Grant Number 15K06847, 18K07215) from the Ministry of Education, Culture, Sports, Science, and Technology (MEXT) of Japan and the Fukuoka Foundation for Sound Health Cancer Research Fund.

\section{References}

1 Colicelli J: Human RAS superfamily proteins and related GTPases. Sci STKE 2004(250): RE13, 2004. PMID: 15367757. DOI: $10.1126 /$ stke.2502004re13

2 Biankin AV, Waddell N, Kassahn KS, Gingras MC, Muthuswamy LB, Johns AL, Miller DK, Wilson PJ, Patch AM, Wu J, Chang DK, Cowley MJ, Gardiner BB, Song S, Harliwong I, Idrisoglu S, Nourse C, Nourbakhsh E, Manning S, Wani S, Gongora M, Pajic M, Scarlett CJ, Gill AJ, Pinho AV, Rooman I, Anderson M, Holmes O, Leonard C, Taylor D, Wood S, Xu Q, Nones K, Fink JL, Christ A, Bruxner T, Cloonan N, Kolle G, Newell F, Pinese M, Mead RS, Humphris JL, Kaplan W, Jones MD, Colvin EK,
Nagrial AM, Humphrey ES, Chou A, Chin VT, Chantrill LA, Mawson A, Samra JS, Kench JG, Lovell JA, Daly RJ, Merrett ND, Toon C, Epari K, Nguyen NQ, Barbour A, Zeps N, Australian Pancreatic Cancer Genome Initiative, Kakkar N, Zhao F, Wu YQ, Wang M, Muzny DM, Fisher WE, Brunicardi FC, Hodges SE, Reid JG, Drummond J, Chang K, Han Y, Lewis LR, Dinh H, Buhay CJ, Beck T, Timms L, Sam M, Begley K, Brown A, Pai D, Panchal A, Buchner N, De Borja R, Denroche RE, Yung CK, Serra S, Onetto N, Mukhopadhyay D, Tsao MS, Shaw PA, Petersen GM, Gallinger S, Hruban RH, Maitra A, IacobuzioDonahue CA, Schulick RD, Wolfgang CL, Morgan RA, Lawlor RT, Capelli P, Corbo V, Scardoni M, Tortora G, Tempero MA, Mann KM, Jenkins NA, Perez-Mancera PA, Adams DJ, Largaespada DA, Wessels LF, Rust AG, Stein LD, Tuveson DA, Copeland NG, Musgrove EA, Scarpa A, Eshleman JR, Hudson TJ, Sutherland RL, Wheeler DA, Pearson JV, McPherson JD, Gibbs RA and Grimmond SM: Pancreatic cancer genomes reveal aberrations in axon guidance pathway genes. Nature 491(7424): 399-405, 2012. PMID: 23103869. DOI: 10.1038/nature11547

3 Neumann J, Zeindl-Eberhart E, Kirchner T and Jung A: Frequency and type of KRAS mutations in routine diagnostic analysis of metastatic colorectal cancer. Pathol Res Pract 205(12): 858-862, 2009. PMID: 19679400. DOI: 10.1016/j.prp.2009.07.010

4 Cancer Genome Atlas Research Network: Comprehensive molecular profiling of lung adenocarcinoma. Nature 511(7511): 543-550, 2014. PMID: 25079552. DOI: 10.1038/nature13385

5 Canon J, Rex K, Saiki AY, Mohr C, Cooke K, Bagal D, Gaida K, Holt T, Knutson CG, Koppada N, Lanman BA, Werner J, Rapaport AS, San Miguel T, Ortiz R, Osgood T, Sun JR, Zhu X, McCarter JD, Volak LP, Houk BE, Fakih MG, O’Neil BH, Price TJ, Falchook GS, Desai J, Kuo J, Govindan R, Hong DS, Ouyang W, Henary H, Arvedson T, Cee VJ and Lipford JR: The clinical KRAS(G12C) inhibitor AMG 510 drives anti-tumour immunity. Nature 575(7781): 217-223, 2019. PMID: 31666701. DOI: $10.1038 / \mathrm{s} 41586-019-1694-1$

6 Biernacka A, Tsongalis PD, Peterson JD, de Abreu FB, Black CC, Gutmann EJ, Liu X, Tafe LJ, Amos CI and Tsongalis GJ: The potential utility of re-mining results of somatic mutation testing: KRAS status in lung adenocarcinoma. Cancer Genet 209(5): 195198, 2016. PMID: 27068338. DOI: 10.1016/j.cancergen.2016. 03.001

7 Stephen AG, Esposito D, Bagni RK and McCormick F: Dragging ras back in the ring. Cancer Cell 25(3): 272-281, 2014. PMID: 24651010. DOI: 10.1016/j.ccr.2014.02.017

8 Jones RP, Sutton PA, Evans JP, Clifford R, McAvoy A, Lewis J, Rousseau A, Mountford R, McWhirter D and Malik HZ: Specific mutations in KRAS codon 12 are associated with worse overall survival in patients with advanced and recurrent colorectal cancer. Br J Cancer 116(7): 923-929, 2017. PMID: 28208157. DOI: $10.1038 /$ bjc 2017.37

9 Wiesweg M, Kasper S, Worm K, Herold T, Reis H, Sara L, Metzenmacher $\mathrm{M}$, Abendroth A, Darwiche $\mathrm{K}$, Aigner $\mathrm{C}$, Wedemeyer HH, Helfritz FA, Stuschke M, Schumacher B, Markus P, Paul A, Rahmann S, Schmid KW and Schuler M: Impact of RAS mutation subtype on clinical outcome-a crossentity comparison of patients with advanced non-small cell lung cancer and colorectal cancer. Oncogene 38(16): 2953-2966, 2019. PMID: 30568222. DOI: 10.1038/s41388-018-0634-0

10 Zhou L, Baba Y, Kitano Y, Miyake K, Zhang X, Yamamura K, Kosumi K, Kaida T, Arima K, Taki K, Higashi T, Imai K, 
Hashimoto D, Yamashita Y, Chikamoto A, Beppu T, Tan X and Baba H: KRAS, BRAF, and PIK3CA mutations, and patient prognosis in 126 pancreatic cancers: pyrosequencing technology and literature review. Med Oncol 33(4): 32, 2016. PMID: 26927447. DOI: 10.1007/s12032-016-0745-9

11 Oun R, Moussa YE and Wheate NJ: The side effects of platinum-based chemotherapy drugs: a review for chemists. Dalton Trans 47(19): 6645-6653, 2018. PMID: 29632935. DOI: $10.1039 / \mathrm{c} 8 \mathrm{dt} 00838 \mathrm{~h}$

12 Friberg LE, Henningsson A, Maas H, Nguyen L and Karlsson MO: Model of chemotherapy-induced myelosuppression with parameter consistency across drugs. J Clin Oncol 20(24): 47134721, 2002. PMID: 12488418. DOI: $10.1200 / J C O .2002 .02 .140$

13 Chari RV: Targeted cancer therapy: conferring specificity to cytotoxic drugs. Acc Chem Res 41(1): 98-107, 2008. PMID: 17705444. DOI: 10.1021/ar700108g

14 Pérez-Herrero E and Fernández-Medarde A: Advanced targeted therapies in cancer: Drug nanocarriers, the future of chemotherapy. Eur J Pharm Biopharm 93: 52-79, 2015. PMID: 25813885. DOI: 10.1016/j.ejpb.2015.03.018

15 Tsunoda T, Ota T, Fujimoto T, Doi K, Tanaka Y, Yoshida Y, Ogawa M, Matsuzaki H, Hamabashiri M, Tyson DR, Kuroki M, Miyamoto S and Shirasawa S: Inhibition of phosphodiesterase4 (PDE4) activity triggers luminal apoptosis and AKT dephosphorylation in a 3-D colonic-crypt model. Mol Cancer 11: 46, 2012. PMID: 22830422. DOI: 10.1186/1476-4598-11-46

16 Luo H, Umebayashi M, Doi K, Morisaki T, Shirasawa S and Tsunoda T: Resveratrol overcomes cellular resistance to vemurafenib through dephosphorylation of AKT in BRAFmutated melanoma cells. Anticancer Res 36(7): 3585-3589, 2016. PMID: 27354627.

17 Nishi K, Luo H, Ishikura S, Doi K, Iwaihara Y, Wills L, Baillie GS, Sakata T, Shirasawa S and Tsunoda T: Apremilast induces apoptosis of human colorectal cancer cells with mutant KRAS. Anticancer Res 37(7): 3833-3839, 2017. PMID: 28668883. DOI: 10.21873/anticanres.11762

18 Luo H, Nishi K, Ishikura S, Swain A, Morishige N, Yazaki R, Ohshima T, Shirasawa S and Tsunoda T: Growth suppression of human colorectal cancer cells with mutated KRAS by 3-deazacytarabine in 3D floating culture. Anticancer Res 38(7): 42474256, 2018. PMID: 29970558. DOI: 10.21873/anticanres.12721
19 NPEdia (Natural Products Encyclopedia). Available at: http://www.cbrg.riken.jp/npedia/kw_search.php [Last accessed on June 2, 2021]

20 Levandowsky $M$ and Winter D: Distance between Sets. Nature 234(5323): 34-35, 2018. DOI: 10.1038/234034a0

21 Shirasawa S, Furuse M, Yokoyama N and Sasazuki T: Altered growth of human colon cancer cell lines disrupted at activated Ki-ras. Science 260(5104): 85-88, 1993. PMID: 8465203. DOI: $10.1126 /$ science. 8465203

22 Tsunoda T, Ishikura S, Doi K, Iwaihara Y, Hidesima H, Luo H, Hirose Y and Shirasawa S: Establishment of a three-dimensional floating cell culture system for screening Drugs targeting KRASmediated signaling molecules. Anticancer Res 35(8): 4453-4459, 2015. PMID: 26168486

23 Tsunoda T, Takashima Y, Fujimoto T, Koyanagi M, Yoshida Y, Doi K, Tanaka Y, Kuroki M, Sasazuki T and Shirasawa S: Threedimensionally specific inhibition of DNA repair-related genes by activated KRAS in colon crypt model. Neoplasia 12(5): 397-404, 2010. PMID: 20454511. DOI: 10.1593/neo.10170

24 Niloy MS, Shakil MS, Alif MMH and Rosengren RJ: Using natural compounds to target KRAS mutated non-small cell lung cancer. Curr Med Chem, 2021. PMID: 33645474. DOI: $10.2174 / 0929867328666210301105856$

25 Hashemi S, Sharifi A, Zareei S, Mohamedi G, Biglar M and Amanlou M: Discovery of direct inhibitor of KRAS oncogenic protein by natural products: a combination of pharmacophore search, molecular docking, and molecular dynamic studies. Res Pharm Sci 15(3): 226-240, 2020. PMID: 33088323. DOI: $10.4103 / 1735-5362.288425$
Received May 22, 2021

Revised June 4, 2021

Accepted June 5, 2021 